\title{
C-H Arylation of Nitroimidazoles and Nitropyrazoles Guided by the Electronic Effect of the Nitro Group
}

\author{
Haeun Jung, Seri Bae, Ha-Lim Jang, and Jung Min Joo* \\ Department of Chemistry, Pusan National University, Busan 609-735, Korea. *E-mail: jmjoo@pusan.ac.kr \\ Received May 20, 2014, Accepted June 20, 2014
}

\begin{abstract}
A palladium-catalyzed $\mathrm{C}-\mathrm{H}$ arylation reaction of nitroimidazoles and nitropyrazoles was developed using aryl bromides as arene donors. The electron-withdrawing effect of the nitro group allows for direct $\mathrm{C}-\mathrm{H}$ arylation reactions of the nitro diazoles with high regioselectivity under mild conditions. The new $\mathrm{C}-\mathrm{H}$ arylation approach is thus complementary to nucleophilic substitution reactions, enabling the preparation of complex nitroazole compounds.
\end{abstract}

Key Words : C-H arylation, Nitroimidazole, Nitropyrazole, Palladium

\section{Introduction}

Nitroazoles constitute an important heterocyclic class in medicinal chemistry and materials science. ${ }^{1}$ Activated by reduction in hypoxic cells, nitroazole drugs and drug candidates have been developed to treat cancer and anaerobic bacterial infection, such as metronidazole, tinidazole, and nimorazole. ${ }^{2}$ Also, the nitro group, readily introduced by various nitration methods, is one of the most straightforward ways to provide a nitrogen atom source to heteroarenes,

(a)

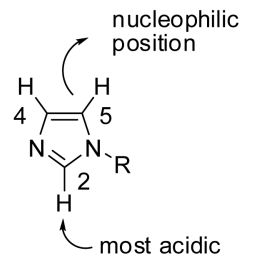

(b)

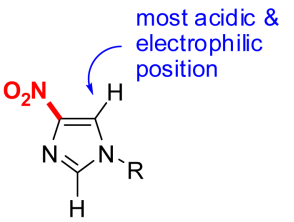

(c)

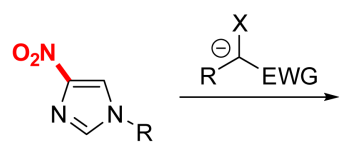

(d) This Work

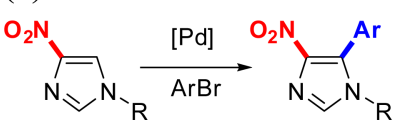

$$
\overbrace{\mathrm{N}-\mathrm{N}_{\mathrm{R}}}^{[\mathrm{Pd}]} \overbrace{\mathrm{NrBr}}^{\mathrm{NO}_{-}}
$$

Figure 1. (a) General reactivity of imidazoles and pyrazoles. (b) General reactivity of nitroimidazoles and nitropyrazoles. The presence of the nitro group renders the C5 positions of the diazoles to be the most acidic, electrophilic, and thus highly reactive for direct $\mathrm{C}-\mathrm{H}$ functionalization. (c) Nitroimidazoles as electrophiles for the vicarious nucleophilic substitution reaction. (d) Regioselective $\mathrm{C}-\mathrm{H}$ arylation of nitroimidazoles and nitropyrazoles. transformed to the amino group by reduction and nitrogencontaining heterocycles by reductive cyclization. ${ }^{3,4}$ Despite the importance of the nitroaromatic compounds, the $\mathrm{C}-\mathrm{H}$ arylation of nitro compounds has been limited to nitrobenzene, pyridine, and pyrazole substrates..$^{5-8}$ Particularly, these studies found that the arylation of nitroheteroarenes required a stoichiometric amount of coinage metal salts, such as $\mathrm{Ag}_{2} \mathrm{CO}_{3}$ and $\mathrm{CuI}$, thus complicating the isolation of products and limiting the scope of substrates.

The general reactivity of simple diazoles suggest that the C5 position of imidazoles and $\mathrm{C} 4$ of pyrazoles are susceptible to electrophilic substitution, whereas the $\mathrm{C}-\mathrm{H}$ bonds at the $\mathrm{C} 2$ of imidazoles and $\mathrm{C} 5$ of pyrazoles are the most acidic (Figure 1(a) and 1(b)). ${ }^{9}$ In contrast, the nitro derivatives of diazoles have been studied mostly in the context of the vicarious nucleophilic substitution reaction by taking advantage of the electron-withdrawing nitro group (Figure 1(c)). ${ }^{10}$ However, the high electrophilicity prevented from the use of strong bases for deprotonation of nitroazoles, thus limiting the synthetic utility of nitroazoles as nucleophiles. We envisioned that the presence of the nitro group should enable both the C5 positions of imidazoles and pyrazoles to be not only electrophilic but also the most acidic, allowing for efficient $\mathrm{C}-\mathrm{H}$ functionalization reactions (Figure 1(d)). Guided by the electronic effect of the nitro group, we have developed a regioselective $\mathrm{C}-\mathrm{H}$ arylation reaction of nitroimidazoles and nitropyrazoles. ${ }^{11}$

\section{Experimental}

General. All solvents were purchased from Sigma-Aldrich (anhydrous, Sure/Seal). All reagents were used as received unless otherwise noted. [ $\left.\mathrm{PCy}_{3} \mathrm{H}\right] \mathrm{BF}_{4}$ was purchased from Alfa Aesar and stored in a dessicator. 4-Nitroimidazole, 4nitropyrazole, dimetridazole (8), and 1-butylimidazole (10) were purchased from TCI.

Analytical thin-layer chromatography (TLC) was performed using glass plates pre-coated with silica gel $(0.25 \mathrm{~mm}, 60$ $\AA$ pore-size) impregnated with a fluorescent indicator (254 
$\mathrm{nm})$. TLC plates were visualized by exposure to ultraviolet light and then were stained by submersion in potassium permanganate solution followed by brief heating on a hot plate. Flash column chromatography was performed on silica gel $(40-63 \mu \mathrm{m})$ using the indicated solvent system. Nuclear Magnetic Resonance spectra were recorded at 300 $\mathrm{K}$ on a 300 Fourier transform NMR spectrometer in $\mathrm{CDCl}_{3}$. Proton chemical shifts are expressed in parts per million (ppm, $\delta$ scale) and are referenced to residual protium in the NMR solvent $\left(\mathrm{CDCl}_{3}, \delta\right.$ 7.26). Data for ${ }^{1} \mathrm{H} \mathrm{NMR}$ are reported as follows: chemical shift, multiplicity ( $\mathrm{s}=$ singlet, $\mathrm{d}=$ doublet, $\mathrm{t}=$ triplet, $\mathrm{q}=$ quartet, $\mathrm{m}=$ multiplet and/or multiple resonances, br $=$ broad), coupling constant $(J)$ in Hertz, and integration. Carbon chemical shifts are expressed in parts per million (ppm, $\delta$ scale) and are referenced to the carbon resonance of the $\mathrm{NMR}$ solvent $\left(\mathrm{CDCl}_{3}, \delta 77.16\right)$. Infrared (IR) spectra were reported in frequency of the absorption $\left(\mathrm{cm}^{-1}\right)$

General Procedures for the Preparation of 1-Alkyl-4nitroazoles. To a stirred solution of 4-nitroimidazole or 4nitropyrazole $(1.00 \mathrm{~g}, 8.84 \mathrm{mmol})$ in DMF $(6.00 \mathrm{~mL})$ at 25 ${ }^{\circ} \mathrm{C}$ were added $\mathrm{K}_{2} \mathrm{CO}_{3}(1.47 \mathrm{~g}, 10.6 \mathrm{mmol})$ and alkyl iodide (10.6 mmol). After stirring for $16 \mathrm{~h}$ at $25^{\circ} \mathrm{C}$, the reaction mixture was treated with water $(15 \mathrm{~mL})$ and EtOAc $(20 \mathrm{~mL})$ and transferred to a $125 \mathrm{~mL}$ separatory funnel. The organic layer was collected and the aqueous layer was extracted with EtOAc $(25 \mathrm{~mL} \times 2)$. The combined organic layers were washed with brine $(20 \mathrm{~mL})$, dried over sodium sulfate and filtered. The filtrate was concentrated, and the residue was purified by flash column chromatography to provide the corresponding alkyl azole.

1-Butyl-4-nitro-1H-imidazole (1). Purification by flash column chromatography $($ EtOAc/hexanes $=2: 1)$ provided butyl imidazole 1 as a white solid ( $1.27 \mathrm{~g}, 85 \%$ yield). $\mathrm{mp}$ 38-40 ${ }^{\circ} \mathrm{C}$; IR (film) 3118, 2958, 2931, 2872, 1544, 1464, $1413 \mathrm{~cm}^{-1} ;{ }^{1} \mathrm{H} \mathrm{NMR}\left(300 \mathrm{MHz}, \mathrm{CDCl}_{3}\right) \delta 7.76(\mathrm{~s}, 1 \mathrm{H}), 7.42$ (s, 1H), 4.02 (t, $J=7.2 \mathrm{~Hz}, 2 \mathrm{H}), 1.90-1.80$ (m, 2H), 1.44$1.31(\mathrm{~m}, 2 \mathrm{H}), 0.98(\mathrm{t}, J=7.3 \mathrm{~Hz}, 3 \mathrm{H}) ;{ }^{13} \mathrm{C} \mathrm{NMR}(75 \mathrm{MHz}$, $\left.\mathrm{CDCl}_{3}\right) \delta 147.4,135.9,119.5,47.7,32.2,19.1,12.9$; HRMS (ESI) calcd for $\mathrm{C}_{7} \mathrm{H}_{12} \mathrm{~N}_{3} \mathrm{O}_{2}[\mathrm{M}+\mathrm{H}]^{+} 170.0930$, found 170.0919 .

1-Benzyl-4-nitro-1H-imidazole (6). ${ }^{12}$ Purification by crystallization (EtOAc/hexanes) provided imidazole $\mathbf{6}$ as a white solid (1.40 g, 78\% yield). ${ }^{1} \mathrm{H}$ NMR $\left(300 \mathrm{MHz}, \mathrm{CDCl}_{3}\right)$ $\delta 7.73(\mathrm{~s}, 1 \mathrm{H}), 7.50(\mathrm{~s}, 1 \mathrm{H}), 7.45-7.39(\mathrm{~m}, 2 \mathrm{H}), 7.28-7.21(\mathrm{~m}$, $3 \mathrm{H}), 5.18$ (s, 2H).

1-Benzyl-4-nitro-1H-pyrazole. Purification by flash column chromatography $($ EtOAc/hexanes $=1: 1)$ provided 1-benzyl4-nitro-1H-pyrazole as a white solid (1.76 g, 98\% yield). Alternatively, the crude product can be crystallized using hexanes and EtOAc. mp 51-53 ${ }^{\circ} \mathrm{C}$; IR (film) 3128, 1455 , $1437,1425,1363,1335 \mathrm{~cm}^{-1} ;{ }^{1} \mathrm{H}$ NMR (300 MHz, $\left.\mathrm{CDCl}_{3}\right) \delta$ $8.10(\mathrm{~s}, 1 \mathrm{H}), 8.05(\mathrm{~s}, 1 \mathrm{H}), 7.45-7.25(\mathrm{~m}, 3 \mathrm{H}), 7.35-7.27(\mathrm{~m}$, 2H), $5.32(\mathrm{~s}, 2 \mathrm{H}) ;{ }^{13} \mathrm{C} \mathrm{NMR}\left(75 \mathrm{MHz}, \mathrm{CDCl}_{3}\right) \delta 135.9$, 134.0, 129.3, 129.1, 128.5, 128.4, 57.4; HRMS (FAB) calcd for $\mathrm{C}_{10} \mathrm{H}_{10} \mathrm{~N}_{3} \mathrm{O}_{2}[\mathrm{M}+\mathrm{H}]^{+}$204.0773, found 204.0775.

1-Methyl-4-nitro-1H-pyrazole. ${ }^{8}$ Purification by flash column chromatography $($ EtOAc/hexanes $=2: 1)$ provided 1 - methyl-4-nitro-1 $H$-pyrazole as a white solid (980 mg, $87 \%$ yield). ${ }^{1} \mathrm{H}$ NMR $\left(300 \mathrm{MHz}, \mathrm{CDCl}_{3}\right) \delta 8.12(\mathrm{~s}, 1 \mathrm{H}), 8.06$ (s, 1H), 3.97 (s, 3H).

General Procedures for the C-H Arylation of Nitroazoles. To a $8 \mathrm{~mL}$ glass vial equipped with a magnetic stir bar were sequentially added $\mathrm{K}_{2} \mathrm{CO}_{3}(207 \mathrm{mg}, 1.5 \mathrm{mmol})$, the nitroazole substrate $(0.50 \mathrm{mmol})$, aryl halide $(0.50 \mathrm{mmol}$ or as indicated), toluene $(0.50 \mathrm{M}$ or $1.0 \mathrm{M}), \mathrm{Pd}(\mathrm{OAc})_{2}(5.60$ $\mathrm{mg}, 0.025 \mathrm{mmol})$ and $\left[\mathrm{PCy}_{3} \mathrm{H}_{3} \mathrm{BF}_{4}(18.4 \mathrm{mg}, 0.050 \mathrm{mmol})\right.$. The reaction mixture was purged with nitrogen through a Teflon-lined cap. Then the cap was replaced with a new Teflon-lined solid cap. The reaction vial was moved to a preheated reaction block. After stirring for $18 \mathrm{~h}$ at the indicated temperature, the reaction mixture was cooled to $25^{\circ} \mathrm{C}$ and concentrated. The residue was purified by flash column chromatography to provide the desired arylated product.

1-Butyl-5-(4-butylphenyl)-4-nitro-1H-imidazole (2). Purification by flash column chromatography $($ EtOAc/hexanes $=$ 2:1) provided arylimidazole 2 as a white solid (103 mg, 68\% yield): $\mathrm{mp} 65-67^{\circ} \mathrm{C}$; IR (film) 2932, 2873, 1574, 1516, 1464, $1340 \mathrm{~cm}^{-1}$; ${ }^{1} \mathrm{H}$ NMR $\left(300 \mathrm{MHz}, \mathrm{CDCl}_{3}\right) \delta 7.49(\mathrm{~s}, 1 \mathrm{H}), 7.37-$ $7.26(\mathrm{~m}, 4 \mathrm{H}), 3.81(\mathrm{t}, J=7.5 \mathrm{~Hz}, 2 \mathrm{H}), 2.70(\mathrm{t}, J=7.7 \mathrm{~Hz}$, $2 \mathrm{H}), 1.75-1.65(\mathrm{~m}, 4 \mathrm{H}), 1.45-1.35(\mathrm{~m}, 2 \mathrm{H}), 1.27-1.17(\mathrm{~m}$, $2 \mathrm{H}), 0.96(\mathrm{t}, J=7.5 \mathrm{~Hz}, 3 \mathrm{H}), 0.82(\mathrm{t}, J=7.3 \mathrm{~Hz}, 3 \mathrm{H}) ;{ }^{13} \mathrm{C}$ NMR $\left(75 \mathrm{MHz}, \mathrm{CDCl}_{3}\right) \delta 145.1,144.3,134.8,132.5,129.8$, 128.8, 123.8, 45.8, 35.5, 33.2, 32.3, 22.3, 19.4, 13.9, 13.3; HRMS (ESI) calcd for $\mathrm{C}_{17} \mathrm{H}_{24} \mathrm{~N}_{3} \mathrm{O}_{2}[\mathrm{M}+\mathrm{H}]^{+} 302.1869$, found 302.1859 .

1-Butyl-2,5-bis(4-butylphenyl)-4-nitro-1H-imidazole (3). Purification by flash column chromatography (EtOAc/ hexanes $=1: 2$ ) provided diarylimidazole 3 as a yellow solid (164 mg, 75\% yield): mp 110-113 ${ }^{\circ} \mathrm{C}$; IR (film) 3028, 2927 , 2858, 1616, 1575, 1541, 1512, $1349 \mathrm{~cm}^{-1} ;{ }^{1} \mathrm{H}$ NMR $(300$ $\left.\mathrm{MHz} \mathrm{CDCl}_{3}\right) \delta 7.55$ (d, $\left.J=8.0 \mathrm{~Hz}, 2 \mathrm{H}\right), 7.34$ (br s, $\left.4 \mathrm{H}\right)$, $7.30(\mathrm{~d}, J=8.1 \mathrm{~Hz}, 2 \mathrm{H}), 3.95-3.85(\mathrm{~m}, 2 \mathrm{H}), 2.80-2.65(\mathrm{~m}$, $4 \mathrm{H}), 1.75-1.60(\mathrm{~m}, 4 \mathrm{H}), 1.45-1.25(\mathrm{~m}, 6 \mathrm{H}), 1.05-0.90(\mathrm{~m}$, $8 \mathrm{H}), 0.60(\mathrm{t}, J=7.3 \mathrm{~Hz}, 3 \mathrm{H}) ;{ }^{13} \mathrm{C} \mathrm{NMR}\left(75 \mathrm{MHz}, \mathrm{CDCl}_{3}\right) \delta$ 146.2, 144.9, 144.8, 143.9, 133.3, 129.8, 129.0, 128.7, 126.4, $124.6,45.3,35.4,35.3,33.2,31.7,29.6,22.2,22.1,19.1$, 13.8, 12.9; HRMS (FAB) calcd for $\mathrm{C}_{27} \mathrm{H}_{36} \mathrm{~N}_{3} \mathrm{O}_{2}[\mathrm{M}+\mathrm{H}]^{+}$ 434.2808, found 434.2806.

1-Butyl-4-nitro-5-phenyl-1H-imidazole (4). Purification by flash column chromatography (EtOAc/hexanes $=2: 1$ ) provided arylimidazole 4 as a white solid (64 mg, 52\% yield): $\mathrm{mp} 42-44{ }^{\circ} \mathrm{C}$; IR (film) 3115, 2959, 2931, 2873, $1565,1509,1460 \mathrm{~cm}^{-1}$; ${ }^{1} \mathrm{H}$ NMR (300 MHz, $\left.\mathrm{CDCl}_{3}\right) \delta 7.57-$ $7.50(\mathrm{~m}, 4 \mathrm{H}), 7.40-7.32(\mathrm{~m}, 2 \mathrm{H}), 3.82(\mathrm{t}, J=7.3 \mathrm{~Hz}, 2 \mathrm{H})$, $1.65-1.57(\mathrm{~m}, 2 \mathrm{H}), 1.28-1.15(\mathrm{~m}, 2 \mathrm{H}), 0.83(\mathrm{t}, J=7.3 \mathrm{~Hz}$, $3 \mathrm{H}) ;{ }^{13} \mathrm{C} \mathrm{NMR}\left(75 \mathrm{MHz}, \mathrm{CDCl}_{3}\right) \delta 134.9,132.3,130.1$, 130.0, 128.9, 126.8, 45.9, 32.4, 19.5, 13.4; HRMS (FAB) calcd for $\mathrm{C}_{13} \mathrm{H}_{16} \mathrm{~N}_{3} \mathrm{O}_{2}[\mathrm{M}+\mathrm{H}]^{+} 246.1243$, found 246.1245.

3-(1-Butyl-4-nitro-1H-imidazol-5-yl)pyridine (5). Purification by flash column chromatography (EtOAc only) provided arylimidazole 5 as a yellow solid $(70 \mathrm{mg}, 57 \%$ yield): mp 92-94 ${ }^{\circ} \mathrm{C}$; IR (film) 3113, 3057, 2959, 2872, 1571, 1501, $1468 \mathrm{~cm}^{-1} ;{ }^{1} \mathrm{H}$ NMR (300 MHz, $\left.\mathrm{CDCl}_{3}\right) \delta 8.78$ $(\mathrm{d}, J=4.7 \mathrm{~Hz}, 1 \mathrm{H}), 8.63$ (br s, $1 \mathrm{H}), 7.78(\mathrm{dt}, J=7.7,1.7 \mathrm{~Hz}$, 
$1 \mathrm{H}), 7.57(\mathrm{~s}, 1 \mathrm{H}), 7.50(\mathrm{dd}, J=7.8,4.9 \mathrm{~Hz}, 1 \mathrm{H}), 3.84(\mathrm{t}, J=$ $7.4 \mathrm{~Hz}, 2 \mathrm{H}), 1.67-1.57$ (m, 2H), 1.30-1.18 (m, 2H), 0.85 (t, $J$ $=7.3 \mathrm{~Hz}, 3 \mathrm{H}) ;{ }^{13} \mathrm{C} \mathrm{NMR}\left(75 \mathrm{MHz}, \mathrm{CDCl}_{3}\right) \delta 151.0,150.2$ 138.0, 135.6, 128.6, 123.6, 123.5, 46.1, 32.4, 19.5, 13.3; HRMS (ESI) calcd for $\mathrm{C}_{12} \mathrm{H}_{15} \mathrm{~N}_{4} \mathrm{O}_{2}[\mathrm{M}+\mathrm{H}]^{+} 247.1195$, found 247.1194 .

1-Benzyl-5-(4-butylphenyl)-4-nitro-1H-imidazole (7). Purification by flash column chromatography (EtOAc/ hexanes $=2: 1$ ) provided arylimidazole 7 as a white solid (117 mg, 70\% yield): $\mathrm{mp} 101-103{ }^{\circ} \mathrm{C}$; IR (film) 2956, 2930, $1515,1498,1342,837 \mathrm{~cm}^{-1} ;{ }^{1} \mathrm{H}$ NMR $\left(300 \mathrm{MHz} \mathrm{CDCl}_{3}\right) \delta$ $7.49(\mathrm{~s}, 1 \mathrm{H}), 7.37-7.26(\mathrm{~m}, 5 \mathrm{H}), 7.23-7.16(\mathrm{~m}, 2 \mathrm{H}), 7.02-$ $6.92(\mathrm{~m}, 2 \mathrm{H}), 4.97$ (s, 2H), $2.67(\mathrm{t}, J=7.6 \mathrm{~Hz}, 2 \mathrm{H}), 1.72-$ $1.62(\mathrm{~m}, 2 \mathrm{H}), 1.45-1.35(\mathrm{~m}, 2 \mathrm{H}), 0.95(\mathrm{t}, J=7.3 \mathrm{~Hz}, 3 \mathrm{H})$; ${ }^{13} \mathrm{C}$ NMR $\left(75 \mathrm{MHz}, \mathrm{CDCl}_{3}\right) \delta 145.2,144.4,135.2,134.5$, 132.8, 130.0, 129.1, 128.8, 127.3, 123.6, 49.8, 35.5, 33.3, 22.4, 14.0; HRMS (FAB) calcd for $\mathrm{C}_{20} \mathrm{H}_{22} \mathrm{~N}_{3} \mathrm{O}_{2}[\mathrm{M}+\mathrm{H}]^{+}$ 336.1712 , found 336.1708 .

1,2-Dimethyl-5-nitro-4-phenyl-1H-imidazole (9). ${ }^{13}$ Purification by flash column chromatography (EtOAc/hexanes $=2: 1$ ) provided arylimidazole $\mathbf{1 0}$ as a light yellow solid (47 $\mathrm{mg}, 44 \%$ yield): ${ }^{1} \mathrm{H} \mathrm{NMR}\left(300 \mathrm{MHz}, \mathrm{CDCl}_{3}\right) \delta$ 7.77-7.67 (m, 2H), 7.47-7.37 (m, 3H), 3.88 (s, 3H), 2.49 (s, 3H).

1-Benzyl-5-(4-butylphenyl)-4-nitro-1H-pyrazole (12). Purification by flash column chromatography (EtOAc/ hexanes $=1: 1$ ) provided mono-arylated pyrazole $\mathbf{1 2}$ as a yellow oil (143 mg, 85\% yield) along with di-arylation product 13 (17 mg, 7\% yield): IR (film) 2956, 2929, 2857, 1615, 1560, 1509, 1444, $1356 \mathrm{~cm}^{-1}$; ${ }^{1} \mathrm{H}$ NMR $(300 \mathrm{MHz}$, $\left.\mathrm{CDCl}_{3}\right) \delta 8.25(\mathrm{~s}, 1 \mathrm{H}), 7.32-7.24(\mathrm{~m}, 5 \mathrm{H}), 7.24-7.17(\mathrm{~m}, 2 \mathrm{H})$, 7.06-7.00 (m, 2H), $5.16(\mathrm{~s}, 2 \mathrm{H}), 2.75-2.65(\mathrm{~m}, 2 \mathrm{H}), 1.72-$ $1.60(\mathrm{~m}, 2 \mathrm{H}), 1.46-1.36(\mathrm{~m}, 2 \mathrm{H}), 0.96$ (t, $J=7.3 \mathrm{~Hz}, 3 \mathrm{H})$; ${ }^{13} \mathrm{C}$ NMR $\left(75 \mathrm{MHz}, \mathrm{CDCl}_{3}\right) \delta 145.6,142.0,136.8,135.4$, $133.2,129.7,128.9,128.8,128.3,127.5,123.6,54.1,35.6$, 33.3, 22.4, 14.0; HRMS (ESI) calcd for $\mathrm{C}_{20} \mathrm{H}_{22} \mathrm{~N}_{3} \mathrm{O}_{2}[\mathrm{M}+\mathrm{H}]^{+}$ 336.1712 , found 336.1708 .

\section{1-Benzyl-3,5-bis(4-butylphenyl)-4-nitro-1H-pyrazole} (13). Purification by flash column chromatography (EtOAc/ hexanes $=1: 3$ ) provided di-arylation product $\mathbf{1 3}$ as a yellow oil (59 mg, 25\% yield) along with mono-arylation product 12 (104 mg, 62\% yield): IR (film) 3033, 2930, 2859, 1616, 1561, 1496, $1321 \mathrm{~cm}^{-1}$; ${ }^{1} \mathrm{H}$ NMR $\left(300 \mathrm{MHz}, \mathrm{CDCl}_{3}\right) \delta 7.61$ $(\mathrm{d}, J=7.9 \mathrm{~Hz}, 2 \mathrm{H}), 7.35-7.20(\mathrm{~m}, 9 \mathrm{H}), 7.10-0.02(\mathrm{~m}, 2 \mathrm{H})$, $5.18(\mathrm{~s}, 2 \mathrm{H}), 2.75-2.60(\mathrm{~m}, 4 \mathrm{H}), 1.70-1.58(\mathrm{~m}, 4 \mathrm{H}), 1.45-$ $1.32(\mathrm{~m}, 4 \mathrm{H}), 1.00-0.90(\mathrm{~m}, 6 \mathrm{H}) ;{ }^{13} \mathrm{C} \mathrm{NMR}\left(75 \mathrm{MHz}, \mathrm{CDCl}_{3}\right)$ $\delta$ 147.6, 145.4, 144.2, 143.4, 135.6, 129.7, 129.1, 128.9, $128.8,128.4,128.2,127.9,127.6,124.3,54.2,35.7,33.6$, 33.4, 22.5, 14.1; HRMS (FAB) calcd for $\mathrm{C}_{30} \mathrm{H}_{34} \mathrm{~N}_{3} \mathrm{O}_{2}$ $[\mathrm{M}+\mathrm{H}]^{+}$468.2651, found 468.2649.

5-(4-Butylphenyl)-1-methyl-4-nitro-1H-pyrazole (14). Purification by flash column chromatography (EtOAc/hexanes $=1: 1)$ provided arylpyrazole $\mathbf{1 4}$ as a yellow oil $(100 \mathrm{mg}$, $77 \%$ yield): IR (film) 2957, 2929, 2859, 1466, $1436 \mathrm{~cm}^{-1}$; ${ }^{1} \mathrm{H}$ NMR $\left(300 \mathrm{MHz}, \mathrm{CDCl}_{3}\right) \delta 8.19$ (s, 1H), 7.34 (d, $J=8.1$ $\mathrm{Hz}, 2 \mathrm{H}), 7.29$ (d, $J=8.3 \mathrm{~Hz}, 2 \mathrm{H}), 3.74$ (s, 3H), 2.70 (t, $J=$ $7.8 \mathrm{~Hz}, 2 \mathrm{H}), 1.72-1.60(\mathrm{~m}, 2 \mathrm{H}), 1.46-1.34$ (m, 2H), 0.95 (t, $J$ $=7.3 \mathrm{~Hz}, 3 \mathrm{H}) ;{ }^{13} \mathrm{C} \mathrm{NMR}\left(75 \mathrm{MHz}, \mathrm{CDCl}_{3}\right) \delta 145.5,141.7$,
$136.4,132.9,129.6,128.8,123.6,38.0,35.6,33.3,22.4$, 14.0; HRMS (FAB) calcd for $\mathrm{C}_{14} \mathrm{H}_{18} \mathrm{~N}_{3} \mathrm{O}_{2}[\mathrm{M}+\mathrm{H}]^{+} 260.1399$, found 260.1396 .

5-(4-Fluorophenyl)-1-methyl-4-nitro-1H-pyrazole (15). Purification by flash column chromatography (EtOAc/hexanes $=2: 1$ ) provided arylpyrazole $\mathbf{1 5}$ as a yellow solid $(93 \mathrm{mg}$, 84\% yield): $\mathrm{mp} 109-111{ }^{\circ} \mathrm{C}$; IR (film) $1607,1511,1472$, 1393, $13261239,1161 \mathrm{~cm}^{-1} ;{ }^{1} \mathrm{H}$ NMR $\left(300 \mathrm{MHz}, \mathrm{CDCl}_{3}\right) \delta$ 8.20 (s, 1H), 7.45-7.35 (m, 2H), 7.30-7.25 (m, 2H), 3.74 (s, $3 \mathrm{H}) ;{ }^{13} \mathrm{C}$ NMR $\left(75 \mathrm{MHz}, \mathrm{CDCl}_{3}\right) \delta 163.8\left(\mathrm{~d},{ }^{1} J_{\mathrm{C}-\mathrm{F}}=251.4\right.$ $\mathrm{Hz}), 140.5,136.4,132.0\left(\mathrm{~d},{ }^{3} J_{\mathrm{C}-\mathrm{F}}=8.9 \mathrm{~Hz}\right), 122.5\left(\mathrm{~d},{ }^{4} J_{\mathrm{C}-\mathrm{F}}=\right.$ $3.6 \mathrm{~Hz}), 116.3\left(\mathrm{~d},{ }^{2} J_{\mathrm{C}-\mathrm{F}}=22.1 \mathrm{~Hz}\right), 38.1$; HRMS (ESI) calcd for $\mathrm{C}_{10} \mathrm{H}_{9} \mathrm{FN}_{3} \mathrm{O}_{2}[\mathrm{M}+\mathrm{H}]^{+} 222.0679$, found 222.0678.

3-(1-Methyl-4-nitro-1H-pyrazol-5-yl)pyridine (16). Purification by flash column chromatography (EtOAc only) provided arylpyrazole 16 as a yellow solid (72 $\mathrm{mg}, 71 \%$ yield): $\mathrm{mp} 141-143{ }^{\circ} \mathrm{C}$; IR (film) $1602,1572,15051411$, 1324, $1247 \mathrm{~cm}^{-1} ;{ }^{1} \mathrm{H}$ NMR $\left(300 \mathrm{MHz}, \mathrm{CDCl}_{3}\right) \delta 8.81(\mathrm{~s}$, $1 \mathrm{H}), 8.67$ (s, 1H), 8.27-8.20 (m, 1H), 7.85-7.75 (m, 1H), 7.58$7.48(\mathrm{~m}, 1 \mathrm{H}), 3.79(\mathrm{~s}, 3 \mathrm{H}) ;{ }^{13} \mathrm{C} \mathrm{NMR}\left(75 \mathrm{MHz}, \mathrm{CDCl}_{3}\right) \delta$ 151.3, 149.9, 138.2, 137.7, 136.4, 123.5, 123.1, 38.2; HRMS (FAB) calcd for $\mathrm{C}_{9} \mathrm{H}_{9} \mathrm{~N}_{4} \mathrm{O}_{2}[\mathrm{M}+\mathrm{H}]^{+} 205.0726$, found 205.0728 .

5-(4-Methoxyphenyl)-1-methyl-4-nitro-1 $\boldsymbol{H}$-pyrazole (17). ${ }^{8}$ Purification by flash column chromatography (EtOAc:hexanes $=1: 1)$ provided arylpyrazole $\mathbf{1 7}$ as a yellow solid $(93 \mathrm{mg}$, 79\% yield): ${ }^{1} \mathrm{H} \mathrm{NMR}\left(300 \mathrm{MHz}, \mathrm{CDCl}_{3}\right) \delta 8.19(\mathrm{~s}, 1 \mathrm{H}), 7.33$ (d, $J=8.4 \mathrm{~Hz}, 2 \mathrm{H}), 7.05$ (d, $J=8.8 \mathrm{~Hz}, 2 \mathrm{H}), 3.89$ (s, 3H), $3.75(\mathrm{~s}, 3 \mathrm{H})$.

\section{Results and Discussion}

Many transition metal-catalyzed $\mathrm{C}-\mathrm{H}$ arylation reactions of diazoles are affected by the strength of the base, requiring strong alkoxide bases or highly soluble carboxylates in polar aprotic solvents. ${ }^{14,15}$ Naturally, base-sensitive functional groups do not tolerate these conditions, including nitroazole compounds. However, we considered that carbonate bases and nonpolar solvents should be sufficient to lead to arylated nitroazoles as nitroazoles are highly reactive due to the presence of the nitro group. ${ }^{16}$ In fact, we observed that the $\mathrm{C}-\mathrm{H}$ arylation reaction of nitroimidazole $\mathbf{1}$ in nonpolar toluene produced 5 -arylated imidazole 2 more selectively than the one in polar DMA, presumably due to the more effective coordination of the palladium complex with the nitro group in the nonpolar medium (Table 1, entries 1 and 2). In lieu of $\mathrm{K}_{2} \mathrm{CO}_{3}, \mathrm{Cs}_{2} \mathrm{CO}_{3}$ can be used for the arylation of nitroimidazoles (Table 1, entry 3 ). These results showed that the base-sensitive nitroazole compounds were tolerant of the carbonate bases at the high temperature. The air-stable, commercially available electron-rich phosphonium salt $\left[\mathrm{PCy}_{3} \mathrm{H}\right] \mathrm{BF}_{4}$ was used on the benchtop for the arylation of nitroazole compounds. In the absence of the ligand, the desired arylation product was not formed (Table 1, entry 4). Neither phenanthroline nor $\mathrm{PPh}_{3}$ was as efficient as the electron-rich phosphine ligand (Table 1 , entries 5 and 6). ${ }^{17}$ However, the conversion was significantly decreased when the reaction was carried out at $100^{\circ} \mathrm{C}$ instead of $120^{\circ} \mathrm{C}$ 
Table 1. Arylation of 4-nitroimidazole 1: Optimization

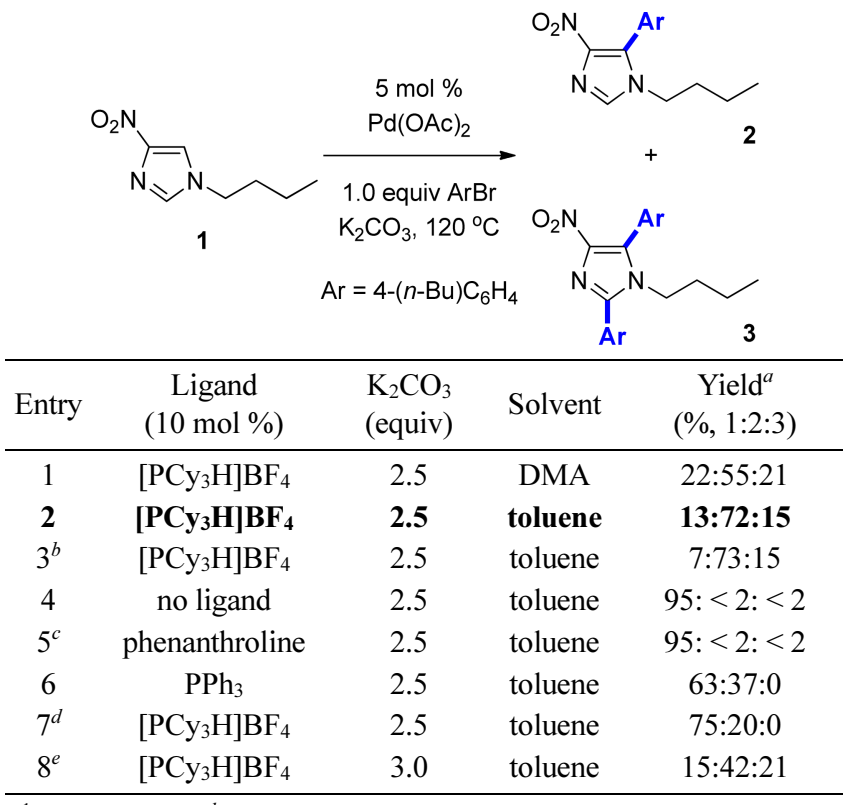

${ }^{a}{ }^{1} \mathrm{H}$ NMR yield. ${ }^{b} \mathrm{Cs}_{2} \mathrm{CO}_{3}$ was used instead of $\mathrm{K}_{2} \mathrm{CO}_{3} \cdot{ }^{c} 5 \mathrm{~mol} \%$ of the ligand was used. ${ }^{d}$ The reaction was carried out at $100{ }^{\circ} \mathrm{C} .{ }^{e} 0.30$ equiv of PivOH was added.

(Table 1, entry 7). The addition of pivalic acid that in situ generates the soluble pivalate base only deteriorated the regioselectivity of the arylation reaction (Table 1, entry 8).

With the optimized conditions in hand, we demonstrated that 1-butyl-4-nitroimidazole 1 gave rise to $\mathrm{C} 5$-arylimidazole 2 and 4 in 68\% and 52\% yields, respectively (Table 2, entries 1 and 2). Functionalized arene donors, such as 3bromopyridine, can also be coupled with the nitroimidazole (Table 2, entry 3). ${ }^{18}$ Furthermore, the enhanced reactivity resulted from the nitro substituent allowed for a di-arylation reaction when an excess of the aryl bromide and a catalytic amount of pivalic acid were used; diarylimidzole $\mathbf{3}$ was obtained in $75 \%$ yield (Table 2 , entry 4 ). In addition, 1benzyl nitroimidazole $\mathbf{6}$ can be used for the $\mathrm{C}-\mathrm{H}$ arylation, affording the corresponding product 7 in $70 \%$ yield (Table 2 , entry 5). The X-ray analysis of product 7 unambiguously confirmed the regioselectivity of the arylation reaction of 4nitroimidazoles (Figure 2). These results consistently indicate that the $\mathrm{C} 5$ position of 4-nitroimidazoles is preferred to the $\mathrm{C} 2$ position for the $\mathrm{C}-\mathrm{H}$ arylation. Not only 4-nitroimidazoles but also 5-nitroimidazole, dimetridazole 8 was arylated (Table 2, entry 6); the result that the arylation took place at the $\mathrm{C} 4$ position that is generally the least reactive in the palladium-catalyzed arylation of imidazoles is another example of the strong activating effect of the nitro group. ${ }^{19}$ More importantly, the observed reactivity is in stark contrast to that of simple imidazole like $\mathbf{1 0}$ that resulted in only a trace amount of the arylation products under the standard toluene conditions (Table 2 , entry 7 ). ${ }^{20}$

The protocol developed for nitroimidazoles can also be applied for the regioselective arylation of nitropyrazoles. Similar to nitroimidazoles, the C5 position of 4-nitropyrazoles was the most reactive, giving 5-arylated pyrazoles in
Table 2. C-H arylation of nitroimidazoles ${ }^{a}$

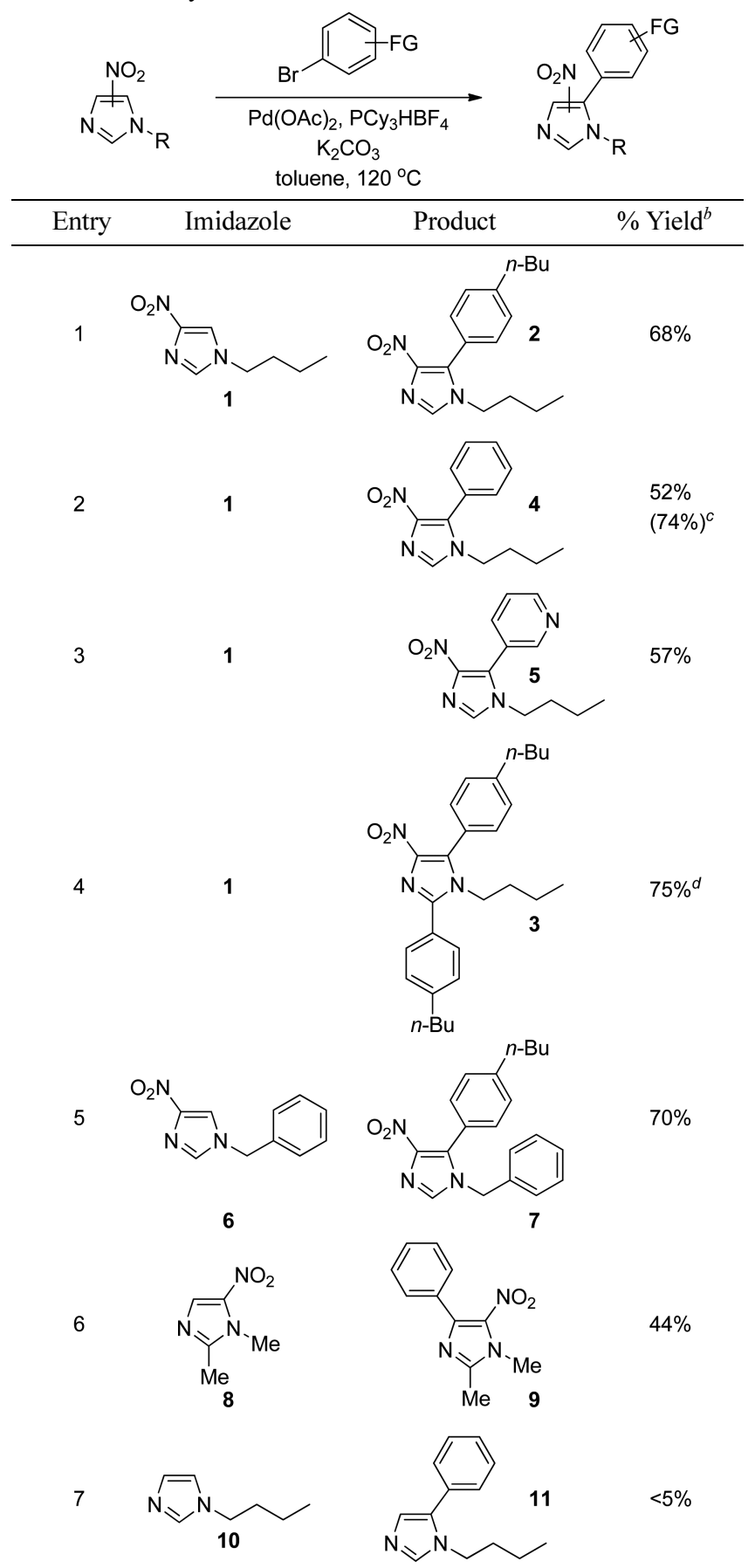

${ }^{a}$ Conditions: $0.50 \mathrm{mmol}$ of the imidazole, 1.0 equiv of $\mathrm{Ar}-\mathrm{Br}, 5.0 \mathrm{~mol} \%$ of $\mathrm{Pd}(\mathrm{OAc})_{2}, 10 \mathrm{~mol} \%$ of $\left[\mathrm{PCy}_{3} \mathrm{H}_{3} \mathrm{BF}_{4}, 2.5\right.$ equiv of $\mathrm{K}_{2} \mathrm{CO}_{3}$, toluene $(0.50 \mathrm{M}), 120^{\circ} \mathrm{C} .{ }^{b}$ Isolated yield. ${ }^{c}{ }^{1} \mathrm{H}$ NMR yield. ${ }^{d} 0.30$ equiv of $\mathrm{PivOH}$, 2.5 equiv of the bromide, and 4.0 equiv of $\mathrm{K}_{2} \mathrm{CO}_{3}$ were used.

high yields (Table 3). The di-arylation of 4-nitropyrazoles was not as efficient as that of 4-nitroimidazoles; when 2.5 equiv of the aryl bromide in conjunction with 0.30 equiv of pivalic acid was used, the di-arylation product 13 was obtained in $25 \%$ yield along with the mono-arylation product 12 in $62 \%$ yield. Not only the $N$-benzylpyrazole but also the $N$-methyl counterpart reacted with a variety of aryl bromides to provide 5 -arylated pyrazoles. Both electron-rich 


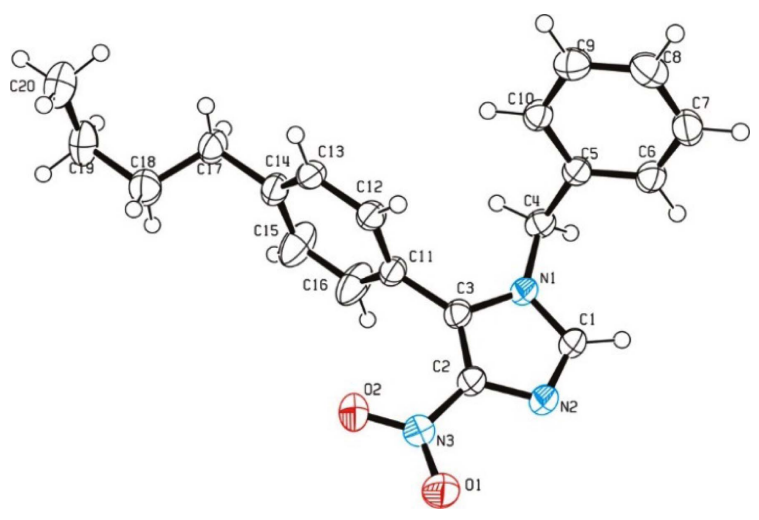

Figure 2. ORTEP diagram of C5-arylated imidazole 7.

and electron-deficient bromoarene donors can be employed for the process. Notably, it was not necessary to include an excess of transition metal additives to prevent the cleavage of the $\mathrm{N}-\mathrm{N}$ bond of the nitropyrazole ring; ${ }^{8}$ the nitropyrazoles were compatible with the mild toluene conditions.

We propose that the $\mathrm{C}-\mathrm{H}$ arylation of nitroazoles occur via concerted metalation/deprotonation (CMD) where the carbonate base is involved in the intramolecular deprotonation (Scheme 1, path a). Given to the highly electrophilic nature of the nitroazole ring, however, we cannot exclude a Heck-type addition/elimination mechanism (Scheme 1, path b). ${ }^{21,22}$ Similar to vicarious nucleophilic substitution reactions, the aryl palladium species could undergo an addition

Table 3. C-H arylation of 4-nitropyrazoles ${ }^{a}$

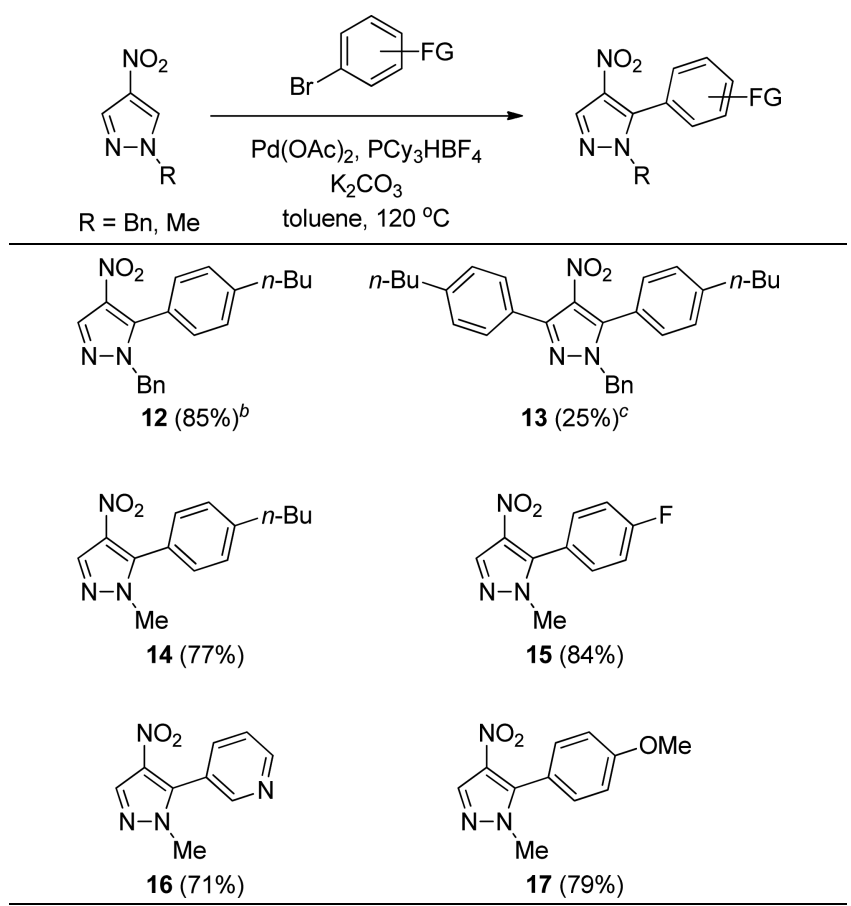

${ }^{a}$ Conditions: $0.50 \mathrm{mmol}$ of the nitropyrazole, 1.0 equiv of $\mathrm{Ar}-\mathrm{Br}, 5.0$ $\mathrm{mol} \%$ of $\mathrm{Pd}(\mathrm{OAc})_{2}, 10 \mathrm{~mol} \%$ of $\left[\mathrm{PCy}_{3} \mathrm{H}\right] \mathrm{BF}_{4}, 3.0$ equiv of $\mathrm{K}_{2} \mathrm{CO}_{3}$, toluene $(1.0 \mathrm{M}), 120{ }^{\circ} \mathrm{C} .{ }^{b}$ The reaction was carried out at $100{ }^{\circ} \mathrm{C} .{ }^{c} 0.30$ equiv of PivOH, 2.5 equiv of the bromide, and 4.0 equiv of $\mathrm{K}_{2} \mathrm{CO}_{3}$ were used.

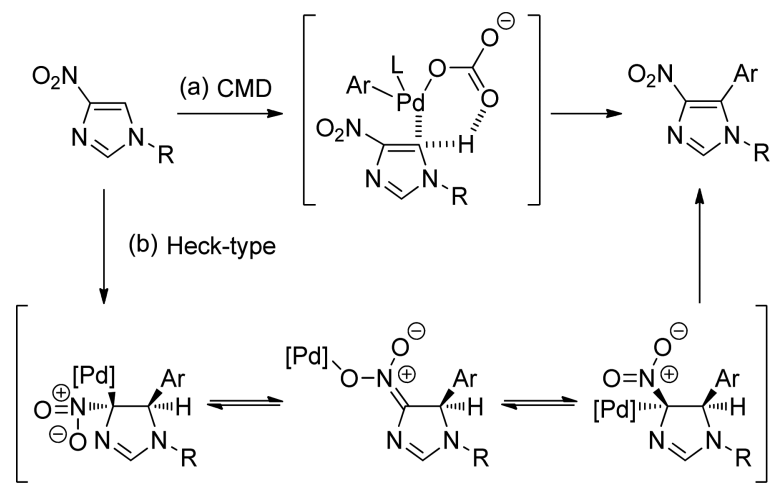

Scheme 1. Proposed mechanism. (a) Concerted metalation/deprotonation (CMD). (b) Heck-type addition/elimination.

to the heterocyclic ring. Subsequent epimerization through the nitro group followed by $\beta-\mathrm{H}$ elimination would restore the aromaticity, giving the arylated azole product.

\section{Conclusion}

In conclusion, we have developed a direct $\mathrm{C}-\mathrm{H}$ arylation reaction of nitroimidazoles and nitropyrazoles using aryl bromides as arene donors. Guided by the electronic character of the nitroazole ring, we have found that a catalytic amount of the palladium complex derived from air-stable $\left[\mathrm{PCy}_{3} \mathrm{H}_{3}\right] \mathrm{BF}_{4}$ and a stoichiometric amount of weak base $\mathrm{K}_{2} \mathrm{CO}_{3}$ resulted in high yields of arylated nitroimidazoles and nitropyrazoles. Under these practical conditions, the base-sensitive nitroazole heterocycles were well tolerated. Combined with vicarious nucleophilic substitution reactions, the direct $\mathrm{C}-\mathrm{H}$ arylation strategy will allow for rapid functionalization of synthetically important nitroazole compounds.

Acknowledgments. This work was supported by a 2-Year Research Grant of Pusan National University. We also thank Jea Eun Park for the preparation of starting materials.

Supporting Information. Copies of ${ }^{1} \mathrm{H}$ and ${ }^{13} \mathrm{C}$ NMR spectra and X-ray crystallographic data of compound 7. Crystallographic data for arylimidazole 7 have been deposited with the Cambridge Crystallographic Data Centre as supplementary publication no. CCDC 995468. These data can be obtained free of charge via http://www.ccdc.cam. ac.uk/conts/retrieving.html or from CCDC, 12 Union Road, Cambridge CB2 1EZ, UK, E-mail: deposit@ccdc.cam.ac.uk (or FIZ, D-76344, Eggenstein-Leopoldshafen, Germany, Email: crysdata@fiz-karlsruhe.de).

\section{References}

1. Lyudmila, L.; Valentin, L. Nitroazoles: Synthesis, Structure and Applications; Springer: New York, 2009.

2. For recent examples, see: (a) Rami, M.; Dubois, L.; Parvathaneni, N.-K.; Alterio, V.; van Kuijk, S. J. A.; Monti, S. M.; Lambin, P.; De Simone, P.; Supuran, C. T.; Winum, J.-Y. J. Med. Chem. 2013, 56, 8512. (b) Duan, Y.-T.; Wang, Z.-C.; Sang, Y.-L.; Tao, X.-X.; Teraiya, S. B.; Wang, P.-F.; Wen, Q.; Zhou, X.-J.; Ding, L.; Yang, 
Y.-H.; Zhu, H.-L. Eur. J. Med. Chem. 2014, 76, 387. (c) Crozet, M. D.; Botta, C.; Gasquet, M.; Curti, C.; Rémusat, V.; Hutter, S.; Chapelle, O.; Azas, N.; De Méo, M.; Vanelle, P. Eur. J. Med. Chem. 2009, 44, 653.

3. (a) The Nitro Group in Organic Synthesis; Ono, N., Ed.; WileyVCH: New York, 2001. (b) Hanan, E. J.; van Abbema, A.; Barrett, K.; Blair, W. S.; Blaney, J.; Chang, C.; Eigenbrot, C.; Flynn, S.; Gibbons, P.; Hurley, C. A.; Kenny, J. R., II.; Kulagowski, J.; Lee, L.; Magnuson, S. R.; Morris, C.; Murray, J.; Pastor, R. M.; Rawson, T.; Siu, M.; Ultsch, M.; Zhou, A.; Sampath, D.; Lyssikatos, J. P. J. Med. Chem. 2012, 55, 10090.

4. For examples of the synthesis of nitrogen-containing heterocycles using nitro groups as the $\mathrm{N}$ atom source, see: (a) Smitrovich, J. H.; Davies, I. W. Org. Lett. 2004, 6, 533. (b) Freeman, A. W.; Urvoy, M.; Criswell, M. E. J. Org. Chem. 2005, 70, 5014. (c) Sanz, R.; Escribano, J.; Pedrosa, M. R.; Aguado, R.; Arnáiz, F. J. Adv. Synth. Catal. 2007, 349, 713.

5. For the $\mathrm{C}-\mathrm{H}$ arylation reaction of heterocycles using a chloride as an activating group, see: (a) Liégault, B.; Petrov, I.; Gorelsky, S. I.; Fagnou, K. J. Org. Chem. 2010, 75, 1047. (b) Mateos, C.; Mendiola, J.; Carpintero, M.; Mínguez, J. M. Org. Lett. 2010, 12, 4924. (c) Yan, T.; Chen, L.; Bruneau, C.; Dixneuf, P. H.; Doucet, H. J. Org. Chem. 2012, 77, 7659.

6. Caron, L.; Campeau, L.-C.; Fagnou, K. Org. Lett. 2008, 10, 4533.

7. Guo, P.; Joo, J. M.; Rakshit, S.; Sames, D. J. Am. Chem. Soc. 2011, 133, 16338.

8. During the preparation of the manuscript, a $\mathrm{C}-\mathrm{H}$ arylation reaction of 4-nitropyrazoles using a catalytic amount of $\mathrm{Pd}$ or $\mathrm{Ni}$ complexes, an excess of CuI, and DMF was reported. Iaroshenko, V. O.; Gevorgyan, A.; Davydova, O.; Villinger, A.; Langer, P. J. Org. Chem. 2014, 79, 2906.

9. (a) Goikhman, R.; Jacques, T. L.; Sames, D. J. Am. Chem. Soc. 2009, 131, 3042. (b) Joo, J. M.; Touré, B. B.; Sames, D. J. Org. Chem. 2010, 75, 4911.

10. Review: Mąkosza, M.; Wojciechowski, K. Chem. Rev. 2004, 104, 2631.

11. Reviews on catalytic $\mathrm{C}-\mathrm{H}$ bond functionalization reactions: (a) Kakiuchi, F.; Chatani, N. Adv. Synth. Catal. 2003, 345, 1077. (b) Alberico, D.; Scott, M. E.; Lautens, M. Chem. Rev. 2007, 107, 174. (c) Satoh, T.; Miura, M. Chem. Lett. 2007, 36, 200. (d) Seregin, I. V.; Gevorgyan, V. Chem. Soc. Rev. 2007, 36, 1173. (e) Chen, X.; Engle, K. M.; Wang, D.-H.; Yu, J.-Q. Angew. Chem.,
Int. Ed. 2009, 48, 5094. (f) Colby, D. A.; Bergman, R. G.; Ellman, J. A. Chem. Rev. 2010, 110, 624. (g) Lyons, T. W.; Sanford, M. S. Chem. Rev. 2010, 110, 1147. (h) Yamaguchi, J.; Yamaguchi, A. D.; Itami, K. Angew. Chem. Int. Ed. 2012, 51, 8960.

12. Crozet, M. D.; Suspène, C.; Kaafarani, M.; Crozet, M. P.; Vanelle, P. Heterocycles 2004, 63, 1629.

13. Crozet, M. D.; Zink, L.; Remusat, V.; Curti, C.; Vanelle, P. Synthesis 2009, 18, 3150 .

14. (a) For a comprehensive review on the $\mathrm{C}-\mathrm{H}$ arylation of heteroarenes, see: Bellina, F.; Rossi, R. Tetrahedron 2009, 65, 10269. (b) For a review on the carboxylate-assisted $\mathrm{C}-\mathrm{H}$ functionalization reaction, see: Ackermann, L. Chem. Rev. 2011, 111, 1315.

15. Due to the high reproductive toxicity, the European Chemicals Agency (ECHA) has prioritized DMF and DMA in the candidate list of substances of very high concern to be subject to authorization under the REACH regulation. For an example of a solvent selection guideline from a pharmaceutical company, see: Prat, D.; Pardigon, O.; Flemming, H.-W.; Letestu, S.; Ducandas, V.; Isnard, P.; Guntrum, E.; Senac, T.; Ruisseau, S.; Paul Cruciani, P.; Hosek, P. Org. Process Res. Dev. 2013, 17, 1517.

16. A similar electronic effect was observed in the arylation of 1,2,4triazoles that are more electron deficient than 1,2- and 1,3diazoles. Joo, J. M.; Guo, P.; Sames, D. J. Org. Chem. 2013, 78, 738.

17. In the presence of $\mathrm{PPh}_{3}$, the corresponding phenylazoles were resulted from oxidative addition of the $\mathrm{Ph}-\mathrm{P}$ bond.

18. Just like 4-nitropyrazoles (Table 3), 4-nitroimidazoles were coupled with a variety of bromoarenes to give 5 -arylated products in an efficient manner. However, the 4-nitroimidazoles and corresponding $\mathrm{C} 5$-arylated products have a similar polarity that prohibits the isolation of the products by conventional isolation methods.

19. Shibahara, F.; Yamaguchi, E.; Murai, T. J. Org. Chem. 2011, 76, 2680.

20. For a $\mathrm{C}-\mathrm{H}$ arylation of 1-butylimidazole, see: Chiong, H. A.; Daugulis, O. Org. Lett. 2007, 9, 1449.

21. For an example of $\mathrm{C}-\mathrm{H}$ arylation of heterocycles through addition/elimination, see: Tobisu, M.; Hyodo, I.; Chatani, N. J. Am. Chem. Soc. 2009, 131, 12070.

22. For an oxidative Heck reaction of nitroalkenes, see: Denmark, S. E.; Schnute, M. E. J. Org. Chem. 1995, 60, 1013. 